\title{
La infección por el papilomavirus cervicovaginal es muy prevalente y generalmente autolimitada
}

Natural History of Cervicovaginal Papillomavirus Infection in Young Women. Ho GYF, Bierman R, Beardsley L et al. N Eng J Med 1998; 338: 423-8

\section{Objetivo}

Evaluar la historia natural de la infección cervicovaginal por HPV (papillomavirus humano). Conocer si esta historia natural es diferente entre los tipos de HPV relacionados con el cáncer cervical y los otros tipos de HPV.

Diseño

Estudio prospectivo de cohortes.

lugar

New Jersey, E.E.U.U.

Pacientes

Participaron 608 estudiantes universitarias.

\section{Evaluación de factores pronósticos}

En cada visita semestral (seguimiento máximo de tres años) se relevaban datos sobre el estilo de vida y el comportamiento sexual de las participantes y se les realizaba un Lavado vaginal. En la primera consulta y luego en forma anual, se realizaba una toma para citología cervical y un tacto vaginal.

Medición del resultado principal.

El material cervicovaginal se utilizó para la determinación y tipificación de HPV, por medio de la reacción en cadena de la polimerasa y la hibridación por Southern blot.

Se estimaron las probabilidades acumuladas de adquirir o revertir la infección por HPV y de tener una alteración citológica cervical. Se identificaron los factores de riesgo independiente* para padecer una infección (si no la tenía al inicio) o para desarrollar una infección persistente ( = de 6 meses). La incidencia* de un serotipo específico se analizó en aquellas mujeres que en la primera consulta eran HPV negativas o estaban infectadas con un serotipo diferente. Se evaluó la incidencia* de lesiones escamosas intraepiteliales (LIE) en las portadoras de HPV.

\section{Resultados}

El seguimiento promedio fue de 2.2 años. La mediana* del total de consultas por participante fue 5 . El promedio de edad de las mujeres fue de 20 años. La prevalencia* basal de HPV fue de $26 \%$.

La incidencia* acumulada de HPV a los 3 años fue del $43 \%$ en las inicialmente libres de HPV. (IC95\% 39\%-49\%). Esta incidencia disminuía con el transcurso del tiempo (20\% en el primer año, $14 \%$ en el segundo y $9 \%$ en el tercero).

Los factores de riesgo para desarrollar una infección fueron: edad más joven, consumo de alcohol, más de un compañero sexual en el último año, práctica de sexo anal, frecuencia semanal de relaciones $=2-6 / \mathrm{se}-$ mana. Otros fueron el número de compañeras sexuales de su compañero. Los factores de riesgo para desarrollar una infección persistente fueron: edad mayor, infección con múltiples tipos o un tipo viral de alto riesgo. El cigarrillo fue protector para infección persistente. Se encontraron 31 casos LIEs (dos de alto grado). Las mujeres expuestas al HPV desde el comienzo del estudio tuvieron una prevalencia de lesiones intraepiteliales escamosas tres veces superior a las HPV negativas (IC95\% 2-7 veces). El riesgo de estas lesiones aumentaba con la duración de la infección y con los tipos virales de alto riesgo.

La mediana* de duración de la infección por HPV fue de 8 meses (IC95\% 7-10). Un año después de la infección, esta se había resuelto en el 70\% de las mujeres; y luego de dos años sólo el $9 \%$ persistía infectada.

\section{Conclusiones}

La incidencia* promedio anual de HPV fue del $14 \%$ en mujeres universitarias sexualmente activas. El $60 \%$ de ellas tuvo una infección por HPV en algún momento del estudio, y la gran mayoría de estas fue autolimitada. Debido a esto los autores señalan que en las adolescentes y en las mujeres jóvenes, la manifestación del HPV, en particular la LIE de bajo grado, requiere una conducta conservadora.

\section{COMENTARIO}

La Infección genital por HPV es una infección común entre los adultos sexualmente activos. El $1 \%$ presentan verrugas visibles, y cuando se busca la presencia del virus por pruebas de DNA se constata infección subclínica en un 15\%. Existen algunos tipos de HPV a los que se los ha vinculado con el cáncer cervical (16, 18 y posiblemente 31 y 35)(1). Recordemos que hasta el momento la única práctica preventiva que demostró disminuir la mortalidad por cáncer de cuello es el examen citológico con la técnica de Papanicolau, y que la colposcopía sólo se recomienda en mujeres con Papanicolau anormal. Dada la elevada proporción de curaciones espontáneas, los médicos debiéramos preocuparnos por ser un poco más conservadores frente a este tipo de infección y evitar así el furor curandis que predica la eliminación de toda lesión compatible con HPV. La subjetividad de los métodos morfológicos tiene como inconveniente el incremento en la utilización de servicios, el sobrediagnóstico y el sobretratamiento de estas lesiones generalmente benignas y autolimitadas (2). Esto también provoca co- mo consecuencia costos excesivos. Para la práctica clínica el mensaje es que frente a una LIE de bajo grado la conducta puede ser expectante y repetir el Pap en un año, sobre todo en las más jóvenes. Si la LIE es de mediano 0 alto grado, o si se informa anomalía escamosa de significado incierto, la indicación sería colposcopía. A pesar de que algunos tipos virales se asocien más al cáncer cervical, los tests para su detección no se encuentran ampliamente disponibles, y resta esperar que efecto producirán en el cuidado de nuestras pacientes (3).

*Ver glosario 